Tohoku J. exp. Med., 1980, 130, 97-100

\title{
A High Skin Protoporphyrin Level in Erythropoietic Protoporphyria
}

\author{
Takashi Miura, Wakio Torinuki and Yutaka Morihana* \\ Department of Dermatology, Tohoku University School of Medicine, \\ Sendai 980 and *Kobe Children's Hospital, Kobe 654
}

Mtura, T., Torinuki, W. and Morihana, Y. A High Skin Protoporphyrin Level in Erythropoietic Protoporphyria. Tohoku J. exp. Med., 1980, 130 (1), 97-100 - A high skin protoporphyrin level ( $4.36 \mu \mathrm{g} / \mathrm{g}$ wet weight) was detected in a 14year-old girl with erythropoietic protoporphyria who died of protoporphyrin hepatopathy cirrhosis. Excess protoporphyrin was detected in the skin by our assay technique which was assumed to cause severe skin photosensitivity. —_ skin protoporphyrin; photosensitivity; erythropoietic protoporphyria; liver cirrhosis

It is well known that hepatopathy is sometimes associated with erythropoietic protoporphyria (EPP), and in a few cases the hepatopathy resulted in juvenile deaths (Cripps et al. 1977).

We report here a 14-year-old girl with EPP who died of protoporphyrin hepatopathy cirrhosis. Biochemical analysis of porphyrin showed a high protoporphyrin level not only in the liver but also in the skin where a severe photosensitivity was observed before her death.

\section{Case Report}

A 14-year-old girl was admitted to the Children's Hospital Kobe in September 1976 complaining of general fatigue and jaundice. She has been sensitive to sunlight and she used to develop erythematous eruption on the exposed areas after a short time exposure to sunlight; sometimes blisters occurred and they healed leaving small scars. In the family her mother and an elder sister were also sensitive to sunlight.

Physical examination revealed white scars of varying sizes scattering on the face and dorsa of hands and a diffuse brown-black pigmentation on the face, arms, and trunk.

Laboratory examination revealed anemia (RBC $295 \times 10^{4}, \mathrm{Hb} 6.8 \mathrm{~g} / 100 \mathrm{ml}$, platelets $5.2 \times 10^{4}$ ) and bleeding tendency (bleeding time over $10 \mathrm{~min}$; prothrombin time over $5 \mathrm{~min}$; partial prothrombin time over $5 \mathrm{~min}$ ). Liver function was moderately disturbed (serum total bilirubin 3.32, direct bilirubin 2.44, indirect bilirubin $0.88 \mathrm{mg} / 100 \mathrm{ml}$; serum GOT 250, GPT 93 Karmen units; ZTT 18.6 units). Porphyrin examination revealed a high protoporphyrin level in blood and an excess excretion of coproporphyrin in the urine (Table 1). Her elder sister also showed a high blood protoporphyrin level.

Received for publication, January 19, 1979. 
She died 15 months after the admission because of a severe attack of hematoemesis in spite of careful managements including symptomatic blood transfusions. Autopsy specimens were obtained from the liver and the skin and they were examined.

Histology of the liver showed a marked fibrosis with obstructions of small bile ducts with amorphous brown pigments; the latter fluoresced in reddish color when examined under a fluorescent microscope. The findings obtained corresponded to those in portal liver cirrhosis which was caused by deposition of porphyrin pigment. Histology of the skin showed PAS-positive substances in the papillae; this was one of the characteristic findings in EPP.

Extraction and biochemical estimation of porphyrin were carried out on

TABLE 1. Quantitative determination of porphyrins (Rimington's methods)

\begin{tabular}{|c|c|c|c|c|c|c|}
\hline & \multicolumn{2}{|c|}{$\begin{array}{c}\text { Red blood cell } \\
(\mu \mathrm{g} / 100 \mathrm{ml} \text { RBC })\end{array}$} & \multicolumn{2}{|c|}{$\begin{array}{c}\text { Urine } \\
(\mu \mathrm{g} / \text { day })\end{array}$} & \multicolumn{2}{|c|}{$\begin{array}{c}\text { Faeces } \\
(\mu \mathrm{g} / \mathrm{g} \text { dry wt) }\end{array}$} \\
\hline & $\begin{array}{l}\text { Proto- } \\
\text { porphyrin }\end{array}$ & $\begin{array}{l}\text { Copro- } \\
\text { porphyrin }\end{array}$ & $\begin{array}{l}\text { Copro- } \\
\text { porphyrin }\end{array}$ & $\begin{array}{l}\text { Uro- } \\
\text { porphyrin }\end{array}$ & $\begin{array}{l}\text { Proto- } \\
\text { porphyrin }\end{array}$ & $\begin{array}{l}\text { Copro- } \\
\text { porphyrin }\end{array}$ \\
\hline The present case & 13010.9 & 213.5 & 225.0 & 58.9 & - & 一 \\
\hline Elder sister & 1119.3 & 13.2 & 14.0 & 0 & 670.8 & 4.9 \\
\hline Normal range & $4-52$ & $0-4$ & $0-161$ & $5-130$ & $0-76$ & $0-20$ \\
\hline
\end{tabular}

TABLE 2. Relative proportions of porphyrins with 2 to 8 carboxyl groups

\begin{tabular}{|c|c|c|c|c|c|c|c|}
\hline & $\begin{array}{l}\text { Proto- } \\
\text { porphyrin }\end{array}$ & $\begin{array}{l}\text { Tricarboxylic } \\
\text { porphyrin }\end{array}$ & $\begin{array}{l}\text { Copro- } \\
\text { porphyrin }\end{array}$ & $\begin{array}{r}\text { Penta. } \\
\text { car }\end{array}$ & $\begin{array}{l}\text { Hexa- } \\
\text { ylic porp }\end{array}$ & $\begin{array}{l}\text { Hepta- } \\
\text { rin }\end{array}$ & $\begin{array}{l}\text { Uro- } \\
\text { porphyrin }\end{array}$ \\
\hline \multicolumn{8}{|l|}{ The present } \\
\hline case Urine & 0.9 & 1.0 & 80.8 & 1.7 & 5.0 & 2.7 & 8.0 \\
\hline Liver & 93.0 & 0 & 0 & 0 & 0 & 4.0 & 3.0 \\
\hline Skin & 100.0 & 0 & 0 & 0 & 0 & 0 & 0 \\
\hline \multicolumn{8}{|l|}{ Elder sister } \\
\hline $\mathrm{RBC}$ & 71.4 & 14.3 & 14.3 & 0 & 0 & 0 & 0 \\
\hline
\end{tabular}

Numbers in the table show percentages of the total porphyrin extracted. Total liver porphyrin was $432.1 \mu \mathrm{g} / \mathrm{g}$ wet wt, and total skin porphyrin was $4.36 \mu \mathrm{g} / \mathrm{g}$ wet wt.

TABLE 3. Skin porphyrin levels in

\begin{tabular}{clcc} 
Case & \multicolumn{1}{c}{ Diagnosis } & $\begin{array}{c}\text { Total porphyrin } \\
\text { estimated } \\
(\mu \mathrm{g} / \mathrm{g} \text { wet } \mathrm{wt})\end{array}$ & Protoporphyrin \\
\hline $49 \mathrm{M}$ & Porphyria cutanea tarda & 1.21 & $0^{*}$ \\
$52 \mathrm{M}$ & Porphyria cutanea tarda & 0.47 & 0 \\
$2 \mathrm{M}$ & Congenital porphyria & $0^{*}$ & 0 \\
$14 \mathrm{~F}$ & The present case (EPP) & 4.36 & 100.0 \\
$1 \mathrm{~F}$ & Neurofibromatosis & $0^{*}$ & 0 \\
$60 \mathrm{M}$ & Malignant melanoma & $0^{*}$ & 0 \\
$40 \mathrm{M}$ & Osteosarcoma & 1.07 & 0 \\
$50 \mathrm{M}$ & Osteosarcoma & 0.71 & 100.0 \\
\hline
\end{tabular}

0* denotes that faint reddish spots were detected on TLC plates, and the porphyrin 
the liver and the skin specimens according to the combined technique of thin-layer chromatography with fluorescent scanning analysis (Miura and Torinuki 1978) together with the same procedure on the urine and red blood cells (Table 2). In the urine, coproporphyrin predominated, and both in liver and skin protoporphyrin predominated as shown in the table. Total liver porphyrin was $432.1 \mu \mathrm{g} / \mathrm{g}$ wet weight, and its distribution pattern was protoporphyrin $(93.0 \%)>$ heptacarboxylic porphyrin $(4.0 \%)>$ uroporphyrin $(3.0 \%)$. Skin porphyrin estimated was $4.36 \mu \mathrm{g} / \mathrm{g}$ wet weight, and no porphyrins other than protoporphyrin were detected from skin specimen as shown in Fig. 1.

Skin porphyrin estimation was carried out on 3 other cases with porphyria and 4 control subjects; the results obtained were summarized in Table 3 . In 2 cases with porphyria cutanea tarda, skin porphyrin level was 1.21 and $0.47 \mu \mathrm{g} / \mathrm{g}$ wet weight, respectively, with predominance of uroporphyrin likewise in the urine. In 2 control subjects with osteosarcoma, uroporphyrin $(1.07 \mu \mathrm{g} / \mathrm{g}$ wet weight) and protoporphyrin $(0.71 \mu \mathrm{g} / \mathrm{g}$ wet weight) were respectively estimated. In 2 other control subjects and in one case with congential porphyria, skin porphyrin level was so low that it could not be estimated by the assay technique employed (Miura and Torinuki 1978).

Fig. 1. Two-dimensional development of skin porphyrin on a thin-layer chromatography plate.

An aliquot of extracted skin porphyrin was spotted on a left corner of a TLC plate. The plate was developed first in solvent $A$ $(80 \mathrm{ml}$ of toluene, $15 \mathrm{ml}$ of ethyl acetate, $3 \mathrm{ml}$ of ethanol) and then in solvent B (60 $\mathrm{ml}$ of chloroform, $20 \mathrm{ml}$ of white kerosene, $4 \mathrm{ml}$ of ethanol). The developed spot was identified as protoporphyrin whose $\mathrm{Rf}$ value was 0.74 in solvent $A, 0.63$ in solvent $B$, respectively.

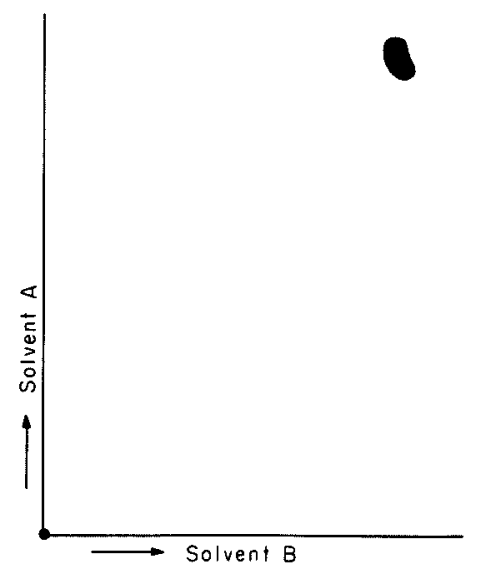

porphyrias and in control subjects

\begin{tabular}{cccccc}
\hline \multicolumn{5}{c}{ Relative proportions $(\%)$} & \\
$\begin{array}{c}\text { Tricarboxylic } \\
\text { porphyrin }\end{array}$ & Coproporphyrin & Penta- & $\begin{array}{c}\text { Hexa- } \\
\text { carboxylic }\end{array}$ porphyrin & Hepta- & Uroporphyrin \\
\hline 0 & $0^{*}$ & 0 & 0 & 0 & 100.0 \\
0 & 0 & 0 & 0 & 0 & 100.0 \\
0 & 0 & 0 & 0 & 0 & $0^{*}$ \\
0 & 0 & 0 & 0 & 0 & 0 \\
0 & 0 & 0 & 0 & 0 & $0^{*}$ \\
0 & 0 & 0 & 0 & 0 & $0^{*}$ \\
0 & 0 & 0 & 0 & 0 & 100.0 \\
0 & 0 & 0 & 0 & 0 & 0
\end{tabular}

contents were so small that they could not be estimated by the assay technique employed. 


\section{Discussion}

Biochemical analysis showed that the present case was a typical one to EPP and she died of portal liver cirrhosis which was confirmed by histological examination employed after her death. It is not common that associated hepatopathy in EPP caused juvenile death. Cripps and coworkers collected 12 cases with EPP who died of protoporphyrin liver cirrhosis in 1977, and 5 other cases including the present one were reported in the literature (Hashimoto et al. 1970; Ibayashi et al. 1975; Pimstone et al. 1976; Miura et al.*1978). Ages of these 17 cases ranged from 11 to 58 years, and juvenile deaths occurred in only 4 teen-agers (16-year-old boy, Meyer et al. 1975; 11-year-old boy, Cirpps et al. 1977; 17-year-old boy, Miura et al.* 1978; 14-year-old girl, the present case).

It is emphasized in the present case that excess protoporphyrin was detected not only in the liver but also in the skin. A large amount of porphyrin $(432.1 \mu \mathrm{g} / \mathrm{g}$ wet weight) was estimated in the liver which consisted mainly of protoporphyrin, and $4.36 \mu \mathrm{g} / \mathrm{g}$ wet weight of protoporphyrin were detected in the skin. In porphyria cutanea tarda, skin porphyrin consisted mainly of uroporphyrin as shown in table 3 ; the predominance of uroporphyrin was also confirmed in the urine. In the present case, however, protoporphyrin was the only porphyrin detected in the skin, and its amount was about 4 -times or more larger than those found in porphyria cutanea tarda or in control subjects. This led us to a conclusion that excess protoporphyrin deposited not only in the liver but also in the skin; the former caused liver cirrhosis which finally led her to juvenile death and the latter, severe photosensitivity which was one of the main complaints before her death.

\section{References}

1) Cripps, D.J., Gilbert, L.A. \& Goldfarb, S.S. (1977) Erythropoietic protoporphyria: juvenile protoporphyrin hepatopathy cirrhosis and death. J. Pediat. 91, 744-748.

2) Hashimoto, K., Kanie, T., Mibukura, Y., Okumura, H., Sakai, Y. \& Kajita, A. (1970) Protoporphyria erythropoietica associated with abnormalities of blood cells: an autopsied case. Rinsho-Ketsu-eki 11, 49-57. (in Japanese with an English abstract).

3) Ibayashi, H., Motomatsu, T., Tomizaki, T., Sakamoto, S., Enjoji, M. \& Matsuzaka, T. (1975) Erythropoietic protoporphyria with hepatopathy. Taisha, 12, 1147-1155. (in Japanese)

4) Meyer, U.A., Fah, P., Knoblauch, M. \& Frick, P. (1975) Protoporphyrin hepatopathy: rare complications of erythropoietic protoporphyria or separate disease? Abstract Porphyrins in Human Disease, International Porphyrin Meeting, Freiburg, p. 57 (quoted from 1)).

5) Miura, T. \& Torinuki, W. (1978) Skin porphyrin and UV-A irradiation. Tohoku J. exp. Med., 125, 199-204.

6) Pimstone, N.R., Webber, B.L., Blekkenhorst, G.H. \& Eales, L. (1976) The hepatic lesion in protoporphyria (PP): preliminary studies of haem metabolism, liver structure and ultrastructure. Ann. clin. Res., 8, Suppl. 17, 122-132.

* Miura, T., Torinuki, W. \& Nakazawa, I.: Two deaths with EPP; reported on East Japan Dermatological Association, 7 Oct., 1978, Tokyo. 